Volume 9 Nomor 3, Desember 2019

Halaman $405-413$

\title{
AMBIVALENSI DALAM PUISI "AMERICA" KARYA ALLEN GINSBERG
}

\author{
Randy Ridwansyah \\ Fakultas Ilmu Budaya, Universitas Padjadjaran \\ randy.ridwansyah@unpad.ac.id
}

\begin{abstract}
Abstrak
Tulisan ini bertujuan untuk memaparkan struktur yang membangun sikap penutur yang ambivalen dalam puisi berjudul "America" karya Allen Ginsberg. Pembahasan difokuskan pada analisis nada yang, menurut Scholes, merupakan unsur paling penting dalam puisi untuk menentukan sikap penutur. Analisis terhadap nada dalam puisinya melibatkan beberapa perangkat puitis yang meliputi majas, diksi, pencitraan dan struktur kalimat.
\end{abstract}

Kata kunci: Allen Ginsberg, puisi, nada, sikap penutur, ambivalensi, Amerika

\begin{abstract}
This article aims to describe the structure that constructs ambivalent speakers' attitude in the poem "America" by Allen Gisberg. It focuses on the analysis of tone which, according to Scholes, is the most important part in a poem that determines speaker's attitude. The analysis of tone in the poem involves several poetic devices, including figures of speech, diction, imagery, and sentence structure.
\end{abstract}

Keywords: Allen Ginsberg, poetry, tone, speaker's attitude, ambivalence, America

\section{PENDAHULUAN}

Allen Ginsberg adalah salah seorang penyair Beat Generation yang karyanya dianggap berpengaruh besar terhadap gerakan counterculture Amerika pasca Perang Dunia II. Salah satu karyanya tersebut adalah puisi yang berjudul "America," yang merepresentasikan protes terhadap kondisi sosio-kultural dan politik di Amerika pada periode itu. Puisi ini diterbitkan pada tahun 1956 dalam buku kumpulan puisi yang berjudul Howl and Other Poems. Sementara itu, istilah counterculture sendiri diperkenalkan oleh Theodore Roszak (1969) dalam membahas gerakan kaum muda, khususnya di Amerika, pada akhir dasawarsa 1950an hingga dua dekade selanjutnya, yang berupaya melepaskan diri dari budaya parentalnya dan mendefinsikan kembali apa yang disebut dengan "American ideals" (42).

Menurut Rozak (1969), akhir Perang Dunia II yang membawa kemakmuran menjadikan Amerika suatu bentuk masyarakat industrial dan materialistik, yaitu suatu bentuk masyarakat yang oleh Roszak (1969) disebut sebagai masyarakat teknokrasi. “By the technocracy, I mean that social form in which an industrial society reaches the peak of its organizational integration" (5). Di satu sisi, kemajuan sains dan teknologi di Amerika pasca Perang Dunia II telah meningkatkan kesejahteraan masyarakatnya. Golongan tua Amerika pada periode tersebut - yang diterpa ketakutan masa perang dan penderitaan 
masa depresi-melihat keadaan tersebut sebagai jaminan untuk mendapatkan rasa aman yang tidak mereka dapatkan di masa lalu (Roszak, 1969: 13). Akan tetapi, di sisi lain, ia juga berpendapat bahwa kemajuan dalam bidang sains dan teknologi tersebut juga telah mengarah pada usaha untuk merasionalisasi hampir semua bidang kehidupan masyarakat. Sistemisasi mekanis industri yang teramat kompleks telah memanjangkan tangannya ke hampir seluruh area kehidupan masyarakat, mulai dari ranah publik hingga ranah privat (6). Amerika berubah menjadi masyarakat industri yang mengerahkan semua sumber dayanya untuk kepentingan efisiensi produksi (18). Dalam masyarakat semacam itu, teknologi menjadi suatu bentuk lembaga yang mengendalikan kehidupan sosial, bahkan kehidupan individu.

Sebagaimana judulnya, puisi America banyak berbicara tentang dan kepada Amerika, yang ditampilkan dalam bentuk metonimi dan personifikasi. Siapa dan apa yang dimaksud dengan Amerika dalam puisinya seringkali berubah-ubah. Kadang yang dimaksud dengan Amerika adalah pemerintah Amerika. Kadang pula yang dimaksud adalah rakyat Amerika serta nilai-nilai ideal pada zamannya. Meski protes, sikap penutur terhadap Amerika tidak selalu konsisten, bahkan sangat cenderung ambivalen. Di satu sisi penutur dalam puisi ini menunjukkan sikapnya yang marah dan kecewa terhadap Amerika, yang kebanyakan muncul dalam bentuk sarkasme. Namun di sisi lain juga terdapat permohonan dan harapan untuk Amerika, bahkan ada kesadaran bahwa ia tidak dapat sepenuhnya melepaskan diri. Ambivalensi tersebut adalah pokok bahasan dalam tulisan ini. Seperti yang dikemukakan Martinez (2003) bahwa, "there can never be such a thing as a true "counterculture." The imbrication of events and sociocultural forces are never simply dichotomous" (25). Oleh karena itu, akan terlalu menyederhanakan masalah jika counterculture dan kebudayaan arus utama ditempatkan dalam posisi yang sepenuhnya berlawanan-golongan muda/golongan tua; liberal/konservatif; marginal/dominan - dan hanya akan membawa pembahasannya pada usaha untuk meromantisasi gerakan counterculture dan trope-tropenya.

\section{METODE PENELITIAN}

Pembahasan dalam tulisan ini akan difokuskan pada bagaimana puisi America menampilkan sikap ambivalen penutur terhadap Amerika dilihat dari penggunaan diksi, struktur kalimat, majas, dan pencitraan.

Berangkat dari teori Scholes (1974) mengenai struktulisme dalam pembahaan karya sastra yang menyebutkan bahwa, pertama, penelitian difokuskan pada kajian intrinsik karya sastra, baik secara parsial maupun secara keseluruhan. Pada tulisan ini, unsur intrinsik puisi yang menjadi perhatian saya adalah diksi, majas, struktur kalimat dan pencitraan yang kesemuanya membentuk apa yang disebut dengan sikap penutur. Kedua, strukturalisme juga mempertimbangkan latar belakang kehidupan sosial kelompok pengarang, karena ia adalah suatu bagian dari komunitas tertentu dan, ketiga, menelaah latar belakang sosio-historis yang melingkupi sebuah karya sastra. di dalam tulisan ini, dalam melakukan pembahasan terhadap puisi America, saya mempertimbangkan konteks historis yang melingkupi kehidupan penyairnya, Allen Ginsberg, sebagai bagian dari gerakan budaya tanding yang dikenal dengan Beat Generation dan kebijakan pemerintah Amerika pasca Perang Dunia II yang dikritisi di dalam puisi tersebut. 


\section{HASIL DAN PEMBAHASAN}

Puisi ini diawali oleh pernyataan penutur yang berbunyi "America I've given you all and now I'm nothing". Pertama, di sini penutur berbicara pada Amerika bahwa ia telah memberikan segalanya sehingga tidak ada yang tersisa dari dirinya. Penutur menggunakan personifikasi melalui penggunaan kata ganti orang kedua you untuk merujuk pada Amerika yang menimbulkan efek seolah-olah Amerika adalah manusia. Selanjutnya, "I've given you all" dalam kalimat tersebut dapat diartikan bahwa penutur telah berkorban atau mengabdi untuk negaranya yang dapat dilihat dari penggunaan present perfect tense yang mengindikasikan bahwa suatu perbuatan telah terjadi atau telah dilakukan. Selanjutnya penutur meneruskan kalimatnya dengan "now I'm nothing" dalam bentuk present tense yang dapat berarti bahwa sekarang penutur sudah tidak punya apa-apa lagi untuk diberikan.

Setelah itu pernyataan tersebut diikuti oleh kalimat-kalimat interogatif pada baris-baris selanjutnya yang juga ditujukan kepada Amerika, misalnya yang pertama terdapat pada baris "America when will we end the human war?". Pada baris ini penutur bertanya kepada Amerika kapan ia akan menghentikan peperangan antara manusia. Kalimat ini dijelaskan oleh kalimat pada baris selanjutnya yaitu "Go fuck yourself with your atom bomb". Dari kalimat kedua dapat diketahui frase kata benda "the human war" atau peperangan antara manusia yang dimaksud oleh penutur pada kalimat sebelumnya itu bersangkutan dengan penggunaan nuklir. Dalam konteks ini kata war (perang) mengacu kepada, pertama, kebijakan pemerintah Amerika dalam penggunaan teknologi nuklir untuk mengebom Jepang pada akhir Perang Dunia II. Kedua, hal ini bersangkutan dengan persaingan antara Amerika Serikat dan Uni Soviet dalam bidang persenjataan nuklir dalam Perang Dingin. Dari konteks yang dibawa kata tersebut, dapat diketahui juga bahwa di sini penutur menggunakan metonimi melalui penggunaan kata America yang sebenarnya merujuk hanya kepada pemerintah Amerika yang, jika dilihat dari konteksnya, dalam hal ini berperan sebagai pembuat kebijakan.

Selain itu, yang juga perlu dibahas dari dua kalimat ini adalah adanya kenaikan nada yang menyebabkan perubahan sikap penutur. Pada kalimat pertama penutur menggunakan kata ganti orang pertama jamak yaitu we yang mengacu pada diri penutur dan Amerika. Dari situ dapat dilihat bahwa penutur memposisikan dirinya sebagai bagian dari Amerika, akan tetapi di sisi lain, pada kalimat selanjutnya penutur dengan jelas menunjukan kekesalannya terhadap Amerika yang dapat dilihat dari penggunaan frase verba "go fuck yourself". Sikap penutur yang kesal dapat diidentifikasi melalui nada dari umpatan tersebut yaitu penggunaan kata fuck yang biasa digunakan untuk mengumpat.

Pada baris selanjutnya penutur kembali mengajukan beberapa pertanyaan kepada Amerika. Yang pertama yaitu "America when will you be angelic?" yang dilanjutkan oleh "When will you take off your clothes?". Pada kalimat yang pertama penutur bertanya kepada Amerika kapan ia akan menjadi "angelic" yang menurut Oxford English Dictionary artinya adalah "like an angel; hence, of superhuman nature, intelligence, innocence, purity, sweetness". Dari pengertian tersebut, jika dibandingkan dengan konteksnya yaitu kebijakan penggunaan bom nuklir, yang perlu digarisbawahi di sini adalah kata innocence (tidak bersalah) dan purity (kesucian/kemurnian). Maksud dari kata sifat angelic dalam konteks ini adalah penutur mempertanyakan perasaan bersalah Amerika terhadap pengeboman di Hiroshima dan Nagasaki. Pada kalimat 
kedua penutur bertanya kapan Amerika akan melepaskan pakaiannya. Dari situ dapat dilihat kalau di sini Amerika juga ditampilkan dalam bentuk personifikasi. Menurut penutur, Amerika harus telanjang untuk dapat menjadi angelic. Pengertian telanjang di sini adalah dalam keadaan seperti apa adanya tanpa atribut apapun sehingga ia dapat menjadi pure (suci/murni) seperti malaikat.

Kalimat selanjutnya masih berbentuk kalimat interogatif, namun di sini pembicaraan penutur tidak lagi mengacu kepada kebijakan penggunaan bom nuklir. Kalimatnya adalah "When will you be worthy of your million Trotskyites?". Di sini penutur mempertanyakan kapan Amerika akan menghargai para pengikut paham Marxism Leon Trotsky. Dilihat dari konteksnya hal ini bersangkutan dengan kebijakan pemerintah Amerika dalam pencegahan pengaruh komunis di dalam negeri. Orangorang yang dicurigai sebagai anggota atau pendukung partai komunis mendapatkan diskriminasi dari pemerintah. Pada baris selanjutnya penutur memberikan pernyataan kepada Amerika yang berbunyi "I'm sick of your insane demands". Pada kalimat tersebut dapat dirasakan adanya kenaikan nada, pertama, dari penggunaan kata sick yang menurut Oxford English Dictionary berarti "thoroughly tired or weary of a thing". Berdasarkan pengertian tersebut, kata sick dalam hal ini dapat diartikan sebagai perasaan sangat muak, lelah, atau, jemu terhadap sesuatu. Pada kalimat di atas, penutur menunjukan sikapnya yang sudah sangat muak terhadap permintaan atau tuntutan yang dibebankan oleh Amerika kepadanya. Kedua, kata demand pada kalimat di atas sebelumnya diterangkan oleh kata insane yang berarti "mad, idiotic, utterly senseless, atau irrational". Maksudnya adalah bahwa penutur merasa kalau tuntutan yang dibebankan Amerika kepadanya itu sudah di luar batas kemampuannya, oleh karena itu dia merasa muak. Jadi pada kalimat ini nada dibentuk oleh penggunaan kata sick dan frase "insane demands" yang keduanya tersebut menunjukan sikap penutur atau kekesalan penutur terhadap Amerika.

Namun setelah menunjukan kekesalannya pada kalimat "I'm sick of your insane demands", nada puisinya kembali menurun. Hal ini dapat diidentifikasi pada kalimat "There must be some other way to settle this argument". Penurunan nada pada kalimat tersebut menunjukan sikap penutur yang masih bersedia untuk mencari cara lain untuk menyelesaikan percekcokannya dengan Amerika, dalam hal ini perbedaan pendapat antara dirinya dan Amerika. Selanjutnya puisi ini dilanjutkan kembali dengan pertanyaan yang berbunyi "Are you [America] being sinister or is this some form of practical joke?". Pada kalimat ini penutur bertanya pada Amerika apakah ia benar-benar sinister, yang menurut Oxford English Dictionary artinya adalah, "Unfavourable, harmful, or prejudicial to a person, his interests, etc.", atau ia hanya sedang bergurau. Saya melihat bahwa pertanyaan ini menunjukan sikap penutur yang masih ragu terhadap Amerika. Penutur masih mengira-ngira apakah Amerika serius dengan perbuatannya atau tidak. Selanjutnya penutur melanjutkanya dengan kalimat "I'm trying to come to the point" dan "I refuse to give up my obsession", lalu dilanjutkan lagi dengan "America stop pushing I know what I'm doing". Dari ketiga kalimat tersebut saya melihat bahwa penutur mencoba untuk meluruskan maksudnya bahwa dia tidak bersedia untuk menurut pada Amerika. Walaupun pada kalimat pertama penutur mengutarakan keinginannya dengan baikbaik, pada kalimat ketiga dapat kembali dilihat adanya kenaikan nada. Jadi bisa dikatakan di sini juga terdapat nada yang turun naik.

Pada baris selanjutnya penutur berkata "America I fell sentimental about the Wooblies". Wooblies pada kalimat tersebut mengacu pada sebutan untuk para pendukung 
International Workers of the World yang menjadi pelopor dari pergerakan kaum buruh di Amerika. Jadi, dilihat dari konteks tersebut, dengan kata lain penutur merasa simpati terhadap pergerakan kaum buruh Amerika yang kurang mendapat perhatian dari pemerintah. Melalui pernyataan yang mengatakan bahwa ia merasa "sentimental" atau kasihan kepada kaum buruh atau Wooblies, penutur secara tidak langsung menyatakan ketidaksetujuannya terhadap kebijakan pemerintah Amerika dalam menyikapi masalah pergerakan kaum buruh. Kalimat ini dilanjutkan oleh baris lain yang berbunyi "America I used to be communist when I was a kid I'm not sorry". Pada kalimat ini penutur mengaku bahwa sewaktu kecil dia adalah seorang komunis, namun dia tidak menyesali itu. Hal ini berkaitan dengan kebijakan pemerintah Amerika dalam pencegahan pengaruh komunis di dalam negeri, jika dibandingkan dengan kalimat sebelumnya yang hanya menunjukan simpati penutur terhadap kaum buruh, pada kalimat ini penutur menunjukan ketidaksetujuannya dengan Amerika secara lebih jelas yang dapat dilihat pada frase "I'm not sorry" yang menunjukan bahwa tidak adanya penyesalan. Lalu pada baris selanjutnya penutur melanjutkannya dengan kalimat "You [America] should have seen me reading Marx". Di sini penutur kembali memperlihatkan sikapnya yang tidak sejalan dengan Amerika. Yang dimaksud penutur dengan Marx di sini adalah Karl Marx dilihat dari konteks dari pernyataan-pernyataan sebelumnya yang menyangkut masalah kaum pekerja. Jadi saya melihat konteks dari kalimat ini masih berhubungan dengan sikap penutur terhadap kaum pekerja di Amerika yang disebutkan pada kalimat sebelumnya.

Pada stanza kedua, penutur mengawali puisinya dengan kalimat " I'm addressing you [America]". Nada pada kalimat ini agak naik dilihat dari makna kalimatnya yang berarti bahwa penutur seperti sedang mempertegas siapa lawan bicaranya, dalam hal ini Amerika. Kalimat ini juga mempertegas bahwa semua pertanyaan dan pernyataan yang terdapat pada stanza sebelumnya ditujukan pada Amerika. Selanjutnya penutur bertanya kembali pada Amerika melalui kalimat "Are you going to let your emotional life be run by Time Magazine?". Pada kalimat ini penutur memulai topik pembicaraan baru yang sedikit berbeda dari topik pembicaran pada kalimat-kalimat sebelumnya. Selain itu, jika sebelumnya penutur berbicara seputar masalah kebijakan penggunaan bom atom, komunisme, dan nasib kaum pekerja yang kesemuanya ditujukan kepada pemerintah Amerika sebagai pembuat kebijakan, pada kalimat ini terdapat perbedaan dalam penggunaan metonimi "America". Kata "America" pada kalimat ini, menurut pengamatan saya, tidak lagi hanya mengacu kepada pemerintah, akan tetapi kepada masyarakat Amerika. Di sini saya melihat bahwa Time Magazine yang dimaksud oleh penutur mengacu kepada majalah Time sebenarnya sebagai media massa, konsumsi masyarakat, dibaca tidak terbatas oleh kalangan pemerintah. Pada kalimat ini penutur bertanya pada masyarakat Amerika apakah mereka akan membiarkan kehidupan emosionalnya diatur oleh majalah Time. Kata sifat emotional pada kalimat tersebut berdasarkan Oxford English Dictionary, artinya adalah "connected with, based upon, or appealing to, the feelings or passions". Dari pengertian tersebut yang perlu digarisbawahi adalah kata passion yang bisa berarti keinginan atau cita-cita, yang berasosiasi dengan kata-kata seperti kesuksesan atau keberhasilan. Berdasarkan hal tersebut saya melihat bahwa maksud penutur pada kalimat di atas adalah bahwa ia mempertanyakan apakah masyarakat Amerika akan membiarkan majalah Time mengatur ide tentang kesuksesan 
atau keberhasilan dalam kehidupan mereka. Akan tetapi pertanyaan ini dilanjutkan oleh komentarnya mengenai majalah Time yaitu:

I'm obsessed by Time Magazine.

I read it every week.

Its cover stares at me every time I slink past the corner

candy store.

I read it in the Basement of Berkeley Public Library.

It's always telling me about responsibility. Businessmen are serious. Movie producers are serious. Everybody's serious but me.

Pada baris pertama kutipan di atas penutur menyatakan bahwa majalah Time menghantui pikirannya. Hal ini menunjukan bahwa secara tidak langsung penutur memposisikan dirinya sebagai bagian dari masyarakat Amerika karena pada kalimat selanjutnya dia menyatakan bahwa "I read it [Time Magazine] every week" yang artinya dia juga membaca majalah Time tiap minggu. Lalu penutur juga menampilkan majalah Time dalam bentuk personifikasi pada kalimat "its cover stares at me..." dan "it's always telling me..." yang, pertama, menimbulkan efek seolah-olah majalah tersebut adalah benda hidup yang mempunyai mata dan bisa menatap penutur. Kedua, penggunaan personifikasi di sini juga mendukung kalimat sebelumnya yaitu "I'm obsessed by Time Magazine". Personifikasi tersebut memperkuat gambaran pikiran penutur yang dihantui oleh Time Magazine, bahwa majalah tersebut mempunyai kontrol atau pengaruh yang kuat terhadap diri penutur. Penutur juga menyebutkan bahwa majalah tersebut selalu mengajarinya tentang keseriusan dan tanggung jawab. Lalu untuk kalimat terakhir pada kutipan di atas yaitu "everybody's serious but me", saya melihatnya dari dua sisi yang berbeda, yang pertama adalah sebagai penolakan penutur terhadap pengaruh Time Magazine, bahwa penutur berbeda dengan orang-orang yang diberitakan oleh majalah tersebut. Yang kedua adalah sebagai kesan penutur, yang dalam hal ini adalah bagian dari rakyat Amerika, tentang dirinya sendiri yang dia dapat setelah membaca majalah tersebut, bahwa apa yang diberitakan majalah tersebut membuatnya merasa menjadi harus seperti orang-orang yang disebutkan oleh Time Magazine.

Selanjutnya, masih pada stanza yang sama, penutur secara tiba-tiba mengganti fokus pembicaraannya dengan menyatakan bahwa "it occurs to me that I am America". Di sini penutur memposisikan dirinya sebagai Amerika. Lalu didikuti oleh baris yang berbunyi "Asia is rising against me". Pada kalimat ini dapat dilihat bahwa penutur adalah Amerika atau dapat juga dikatakan bahwa penutur menyuarakan pikiran Amerika. Ia menyatakan bahwa Asia bangkit melawannya, walaupun sebenarnya di sini terdapat penggunaan metonimi yaitu bahwa sebenarnya jika melihat konteksnya, yang dimaksud dengan Asia pada kalimat tersebut hanya meliputi Cina, Korea Utara, dan Vietnam Utara yang adalah negara-negara Asia berhaluan komunis dan juga merupakan sekutu dari Uni Soviet. Hal ini juga masih berhubungan dengan isu pada baris-baris sebelumnya yaitu the policy of containment atau kebijakan pemerintah Amerika dalam pencegahan pengaruh komunis Soviet di dunia. Pada baris selanjutnya terdapat kalimat "I say nothing about my prisons nor the millions of underprivileged who live in my flowerpots". Pada kalimat ini penutur masih memposisikan dirinya sebagai Amerika. Pada kalimat ini Amerika tidak perduli terhadap penjara yang, menurut pengamatan saya, berasosiasi dengan kata criminal. Berdasarkan itu, saya melihat bahwa 
yang dimaksud dengan "prison" pada kalimat tersebut mempunyai makna yang lebih luas dari sekedar sel penjara. Kalimat tersebut dapat diartikan sebagai kritik terhadap masalah kriminalitas di Amerika. Bahkan bukan hanya tidak perduli terhadap masalah kriminalitas, pada kalimat itu juga penutur menyebutkan bahwa Amerika tidak perduli terhadap para "underprivileged" yang menurut Oxford English Dictionary artinya adalah "less privileged than others; spec. experiencing a standard of living which falls short of an accepted norm, socially disadvantaged. Chiefly applied to persons." Dari pengertian itu saya mengartikan kata "underprivileged" yang dimaksud di sini sebagai kelompok masyarakat yang hidup di bawah garis kemiskinan.

Pada baris selanjutnya penutur kembali memposisikan dirinya bukan sebagai Amerika dan mengganti fokus pembicarannya yang diawali dengan kalimat "America free Tom Mooney". Tom Mooney di sini megacu kepada nama salah satu pemimpin gerakan kaum pekerja di Amerika yang ditahan pada tahun 1919 karena dituduh sebagai pelaku pelemparan bom pada saat San Francisco Preparedness Day Parade yang merupakan peristiwa demonstrasi besar-besaran kaum pekerja pada saat itu. Dia ditahan sampai akhirnya diampuni pada tahun 1939 oleh Gubernur yang menjabat saat itu, Earl Warren. Selama dia ditahan kawan-kawannya sesama kaum pekerja berjuang menuntut agar Mooney dibebaskan dari segala tuduhan. Berdasarkan konteks tersebut, dapat dilihat bahwa penutur kembali mengangkat masalah seputar nasib kaum pekerja. Dapat dilihat pula bahwa pernyataan penutur yang secara lugas menuntut Amerika untuk membebaskan Tom Mooney mengindikasikan sikap penutur yang berpihak kepada kaum pekerja.

Selajutnya penutur melanjutkan puisinya dengan "I am the Scottsboro boys". Pada kalimat ini penutur mengaku bahwa ia adalah "Scottsboro boys" yang dilihat dari latar belakang sejarahnya mengacu kepada sembilan orang pemuda kulit hitam yang dihukum mati karena dituduh sebagai pelaku pemerkosaan dua orang perempuan kulit putih pada tahun 1931 di Scottsboro, Alabama. Kasus ini mengundang perhatian dunia internasional kepada sistem peradilan di Amerika Selatan karena proses peradilannya yang diwarnai nuansa rasial yang kuat. Banyak orang yang meyakini bahwa para pemuda tersebut sebenarnya tidak bersalah, bahwa mereka hanyalah korban dari diskriminasi rasial dalam sistem hukum Amerika bagian Selatan. Berdasarkan konteks tersebut, dapat diketahui bahwa pengakuan penutur pada kalimat di atas menunjukan sikap penutur yang berpihak kepada para pemuda kulit hitam tersebut.

Pada baris selanjutnya penutur bercerita kepada Amerika mengenai pengalamannya saat masih berusia tujuh tahun diajak oleh ibunya ke pertemuan partai komunis. Penutur menyebutkan bahwa orang-orang yang ditemuinya di pertemuan itu sangat baik dan begitu simpati terhadap nasib kaum pekerja. Jika dilihat dari konteksnya, hal ini bertolak belakang dengan anggapan Amerika terhadap orang-orang yang pro Soviet yang pada saat itu dianggap sebagai ancaman sehingga harus diasingkan. Selain Scott Nearing, penutur juga menyebutkan bahwa ia juga pernah bertemu dengan tokoh-tokoh komunis Amerika lainnya seperti Mother Bloor dan Israel Amter. Mother Bloor atau Ella Reeve Bloor adalah seorang orator gerakan komunis yang juga adalah komandan pada saat demonstrasi. Sedangkan Israel Amter juga adalah tokoh gerakan komunis Amerika yang pernah mencalonkan diri sebagai gubernur New York. Penutur menunjukan sikapnya terhadap kedua tokoh tersebut yang dapat dilihat dari, pertama, kalimat "Mother Bloor made me cry". Saya melihat maksud dari kalimat ini 
adalah bahwa penutur bercerita bahwa ia pernah mendengarkan orasi Bloor hingga ia menangis. Hal itu bisa dianggap menunjukan kekaguman penutur terhadap Bloor.

Pada baris selanjutnya nada puisinya menurun dan sikap penutur terhadap Amerika pun berubah karena pernyataannya yaitu "America you don't really want to go to war" dan "America it's them bad Russians". Pada dua kalimat tersebut dapat dilihat penutur berusaha memberitahu Amerika bahwa sebenarnya ia tidak ingin pergi berperang, bahwa Rusia lah yang sebenarnya jahat. Lalu penutur melanjutkannya dengan "Them Russians them Russians and them Chinamen and them Russians". Penutur berulang kali menyebutkan bahwa Rusia dan Cina itu jahat seolah-olah ingin memberitahu Amerika. Di sini penutur menyebut Russia dan Cina jahat karena jika dihubungkan dengan konteksnya yaitu bahwa Russia, atau pada saat itu Uni Soviet, dan Cina merupakan dua negara berhaluan komunis yang sangat berpengaruh di dunia. Pemerintah Amerika menganggap mereka sebagai kekuatan jahat yang mencoba menguasai dunia yang oleh karena itu dikeluarkannya the policy of containment atau kebijakan pemerintah Amerika dalam mencegah pengaruh komunis di dunia yang salah satu caranya adalah dengan memutuskan hubungan diplomatik antara Amerika Serikat dengan Republik Rakyat Cina.

Mulai dari sini dapat diidentifikasi bahwa sikap penutur mulai berubah secara signifikan karena jika dibandingkan dengan pernyataan pada beberapa baris sebelumnya yang masih setengah-setengah.

Pada baris selanjutnya penutur menggunakan personifikasi untuk menggambarkan Rusia yaitu pada kalimat "the Russia wants to eat us alive". Di sini Rusia digambarkan seperti binatang buas yang kelaparan sedangkan Amerika digambarkan sebagai mangsanya yang akan dimakan hidup-hidup. Penutur di sini kembali menggunakan pronomina us yang mengacu pada dirinya dan Amerika. Hal ini menunjukan bahwa penutur merasa sebagai bagian dari Amerika dan memperkuat sikap penutur yang berpihak pada Amerika. Lalu pada baris selanjutnya penutur melanjutkan dengan "America this is quite serious" yang maksudnya adalah untuk menekankan bahwa dia tidak main-main dengan perkataannya, lalu diikuti dengan kalimat "This is the impression I get from looking the televisin set" dan pertanyaan "America is this correct?". Di sini penutur mempertanyakan apakah kesan yang dia tangkap dari menonton televisi itu benar adanya atau tidak. Lalu penutur melanjutkan dengan " $I t$ 's true I don't want to join the army or turn lathes in precision parts factories, I'm nearsighted and psychopathic anyway". Penutur menutup puisinya dengan mengakui bahwa ia memang tidak bersedia bergabung dengan militer atau bekerja di pabrik mengoperasikan mesin bubut. Namun itu karena dia memiliki masalah kejiwaan dan menderita gangguan penglihatan, bukan karena dia tidak bersedia mengabdi kepada Amerika. Hal ini ditegaskan dengan kalimat terkahir dalam puisi ini yang berbentuk ungkapan yaitu "America I'm putting my queer shoulder to the wheel" yang artinya kurang lebih adalah bahwa penutur akan berusaha setengah mati untuk negaranya.

\section{PENUTUP}

Dari keseluruhan pembahasan puisi di atas, hal yang menjadi penting adalah bahwa dalam puisi ini Amerika ditampilkan seperti dibungkam atau dibuat tidak bersuara. Pada beberapa baris penutur malah memposisikan dirinya sebagai Amerika dan menyuarakan pikirannya. Nada pada puisi ini kebanyakan dibangun oleh diksi dan penggunaan kalimat-kalimat interogatif. Penyajian Amerika dalam bentuk personifikasi 
membuat seolah-olah sedang terjadi proses komunikasi langsung antara penutur dan Amerika. Hal ini juga turut membangun nada yang menentukan sikap penutur dalam puisinya. Sikap penutur terhadap Amerika seringkali berubah seiring dengan naik turunnya nada. Di satu sisi penutur membenci beberapa hal yang dilakukan oleh Amerika, misalnya seperti penggunaan bom atom. Namun di sisi lain penutur juga sebenarnya sayang terhadap Amerika dan rela berkorban untuknya.

\section{DAFTAR PUSTAKA}

Dunn, P. (2007). "What If I Sang": The Intonation of Allen Ginsberg's Performances. Style , 65-80.

Ginsberg, A. (1987). Collected Poems 1974-1980. New York: Penguin Books.

Indulal, R. R. (2008). Signs of the Beat: The Image of Beatitude in Allen Ginsberg's Howl and Other Poem. Kerala: Kerala University.

Lawlor, W. (2005). Beat Culture: Lifestyles, Icons, and Impact. California: ABC-CLIO, Inc.

Nowottny, W. (1972). The Language Poets Use. London: The Athlone Press.

Raskin, J. (2004). American Scream: Allen Gisberg's Howl and the Making of Beat Generation. Berkeley and Los Angeles: University of California Press.

Roszak, T. (1969). The Making of A Counter Culture. Garden City, New York, USA: Anchor Books Doubleday \& Company, Inc.

Russell, J. (2002). The Beat Generation. United States of America: Pocket Essetials.

Scholes, R. (1974). Structuralism in Lterature. New Haven and London: Yale University. 